\title{
A!
}

This is an electronic reprint of the original article.

This reprint may differ from the original in pagination and typographic detail.

Kärnä, Sami; Junnonen, Juha Matti

\section{Benchmarking construction industry, company and project performance by participants' evaluation}

Published in:

Benchmarking

DOI:

10.1108/BIJ-05-2015-0050

Published: 01/01/2016

Document Version

Peer reviewed version

Please cite the original version:

Kärnä, S., \& Junnonen, J. M. (2016). Benchmarking construction industry, company and project performance by participants' evaluation. Benchmarking, 23(7), 2092-2108. https://doi.org/10.1108/BIJ-05-2015-0050

This material is protected by copyright and other intellectual property rights, and duplication or sale of all or part of any of the repository collections is not permitted, except that material may be duplicated by you for your research use or educational purposes in electronic or print form. You must obtain permission for any other use. Electronic or print copies may not be offered, whether for sale or otherwise to anyone who is not an authorised user. 
Kärnä, S. and Junnonen, J-M (2016) Benchmarking construction industry, company and project performance by participants'evaluation.

\title{
BENCHMARKING CONSTRUCTION INDUSTRY, COMPANY AND PROJECT PERFORMANCE BY PARTICIPANTS' EVALUATION
}

Sami Kärnä (Department of Civil and Structural Engineering, Aalto University, Espoo, Finland)
Juha-Matti Junnonen (Department of Civil and Structural Engineering, Aalto University, Espoo, Finland)

Citation: Sami Kärnä, Juha-Matti Junnonen, (2016) "Benchmarking construction industry, company and project performance by participants’ evaluation", Benchmarking: An International Journal, Vol. 23 Iss: 7, pp.2092 - 2108

DOI: http://dx.doi.org/10.1108/BIJ-05-2015-0050

\begin{abstract}
Purpose

The construction industry needs effective methods for gathering and utilizing performance information on industry, company and individual project levels. Such benchmarking (BM) information can be collected from project participants' bi-directional evaluations of each other's performance during construction projects. The purpose of this paper is to present the method and discuss the features of a multi-company project evaluation system as a BM tool. Also the accumulated results, based on the extensive BM database in the Finnish construction industry, are investigated.
\end{abstract}

\section{Design/methodology/approach}

The web-based project evaluation tool was established in 2007 as a joint research project between the Helsinki University of Technology, construction organizations and main associations widely representing the construction industry in Finland. The evaluation method is based on soft, subjective measures, such as client satisfaction and project participants' satisfaction. The empirical observations of the study are based on over 5,500 evaluations during which the BM system was used in the Finnish construction industry.

\section{Findings}

The use of the evaluation is presented as a multi-level BM tool to evaluate the performance of different discipline groups on project, company and industry levels. The Finnish case shows an example of the industrylevel performance BMs of project consultants, main contractors, sub-contractors and architects/designers. The BM categories include project management, staff, collaboration and project goal accomplishment. According to the results, the participants are satisfied with each other's performance. However, main development targets in the Finnish industry are related to risk management and managing design. Also, the development of subcontractors' selection procedures will contribute to the performance of the industry.

\section{Practical implications}

Client satisfaction and project participants' satisfaction have been identified as one of the key factors affecting project success. With the help of mutual project evaluation, different BMs enable organizations to monitor their performance and to improve their operations in various areas. They also make it possible to position an organization's performance in comparison to the competitors and help to perceive black spots in the process on project level. As a common system for the parties in the industry, the project evaluation BM system promotes quality improvement, customer orientation and collaboration between participants.

\section{Originality/value}

Multi-company project evaluation is a new and promising topic in performance measurement which holds potential for performance improvement through the utilization of network information and team dynamics. The study presents its wider utility as the basis of national, company and project BM.

Keywords: Performance measurement, Quality improvement, Benchmarking, Client satisfaction, Project management, Project participants’ satisfaction 
Kärnä, S. and Junnonen, J-M (2016) Benchmarking construction industry, company and project performance by participants'evaluation.

\section{INTRODUCTION}

Construction organizations are rethinking their business and project processes under growing competitive pressure. Many initiatives aimed at improving productivity, quality and client satisfaction require information on operational and industrial performance. Since 1990, there has been a growing awareness of performance measurement, such as benchmarking, among the majority of construction organizations (Mohamed, 1996). However, productive improvement and performance measurement have been a challenge in construction and the industry has been found to be not as successful in improving productivity and performance as the manufacturing sector (Nasir et al., 2012). This is merely because, unlike manufacturing, construction is a project-based industry with various locations and although many of the basic processes are repeated from project to project, the specifics of application are always changing (Pheng and Ke-Wei, 1996). It has also been said that in the construction industry, there is lack of methods and standards on how to implement and adapt benchmarking (Fisher, 1995; Lema and Price, 1995) and difficulties in collecting and utilizing relevant benchmarking data (Mohamed, 1996).

Consequently, project-based management is frequently associated with the management of complexity and therefore it affects the project objectives of time, cost and quality (Baccarini, 2006). These three factors have been used widely as basic criteria of project success (Chan and Chan, 2004). Recently, it has been discussed and discovered that project success should also be viewed from the perspectives of the client and the main project participants, such as contractors, project managers, designers and subcontractors (Leung, et al., 2004; Toor and Ogunlana, 2010; Nzekwe-Excel et al., 2010; Lehtiranta et al., 2012).

In a project, a large number of stakeholders (project participants, investors etc.), specifications and objectives refer to organizational complexity (Vidal et al., 2011). The completion of a typical construction project involves bringing together the client and other project participants. They might look at the project from their own perspectives and also have their own criteria for measuring success (Chan and Chan, 2004). These characteristics of projects complicate the evaluation of project outcome and make it difficult to project participants to systematically exploit past experiences in future projects (Kärnä, 2009; Kumaraswamy and Thorpe, 1996). Therefore, a systematic evaluation of the project participants' performance is required to provide feedback for guiding the participants' behavior (Liu and Walker, 1998).

The relationship between the main participants in a construction project constitutes a multilevel complex, in which the parties operate simultaneously and collaborate within groups of networks. It is identified that each participant in the construction process is both a customer and a supplier, and their creation of value is a fundamental factor in successful projects (Love et al., 2000). In the 
Kärnä, S. and Junnonen, J-M (2016) Benchmarking construction industry, company and project performance by participants'evaluation.

construction process, the performances of each participant are also strongly interdependent, where poor performance of one party will affect the performance of the next party (Kanji and Wong, 1998). These interdependencies of the performance of the construction project participants, the main characteristics of the construction project environment, and the prevailing perceptions of project success factors emphasize the importance of the project participants' mutual performance evaluation in the construction project, which can be used as a basis of benchmarking.

Benchmarking is a systematic and continuous process of measuring and comparing an organization's performance against that of other similar organizations in key business activities. Moreover, benchmarking adds value to performance measurement because it allows companies to compare their data and enhance decision-making based on these comparisons (Beatham et al., 2004).

This article introduces and discusses the features and results of the multi-company project evaluation and benchmark system, which was developed in 2007 to serve the Finnish construction industry. The national construction project benchmark system is based on multi-directional standard evaluation wherein the main participants evaluate each other's performances. The BM system produces project participants' satisfaction and project evaluation data, which can be used widely in the companies' internal and external benchmarking as well as from the point of view of the whole industry. In the article, the performance of the Finnish construction industry is also observed from the client and project participant's perspective, which is based on the extensive database of the BM system.

\section{PERFORMANCE MEASUREMENT AND BENCHMARKING}

In general, companies should use multiple tools to measure their ability to develop and monitor products and services to improve their performance and management (Garvin, 1993). Also the construction industry needs performance information collection and utilization systems that are fitted to its project-based, multidisciplinary and multi-stakeholder structure. However, the nature of the industry, its projects, participants and methods of execution differ widely from the manufacturing sector, making traditional benchmarking models developed for manufacturing difficult to adapt (Lee et al., 2005). Furthermore, it is difficult to apply the concepts and principles of benchmarking to construction due to the project-based activities such as different locations, the temporality of each project and the large portion of works carried out on site (Hellard, 2003; Ball, 1998).

In construction, the evaluation of project success can be addressed with the basic criteria of cost, schedule and quality, which have traditionally been used as hard key performance indicators (KPIs) in construction (Chan and Chan, 2004). KPIs are performance standards that focus on factors critical to the success of an organization or project. They provide information about the current situation, which then can be used to set targets to focus the change strategy. Also with the help of KPIs, 
Kärnä, S. and Junnonen, J-M (2016) Benchmarking construction industry, company and project performance by participants'evaluation.

companies can identify the best practices for developing their operations (CCI, 2004). However, hard measures have also been criticized for that they are too simple to measure the complex construction project environment (Dainty et al., 2003).

Recently, soft KPIs, such as customer satisfaction and project participants' satisfaction, have been identified as one of the main factors indicating project success and they complement the objective performance criteria (Cheung et al., 2000; Leung et al., 2004; Wang and Huang, 2006; Nzekwe-Excel et al., 2010). Hard KPIs are objective measures of construction, typically taken from external records and various project control systems. On the contrary, soft KPIs rely on subjective measures as reported by respondents and can be collected through questionnaire or interview surveys that simultaneously elicit information on practices (Chan and Chan, 2004; Wall et al., 2004). Interestingly, Wall et al. (2004) found that the relationships of subjective and objective company performance measures with a range of independent variables were equivalent (construct validity) and suggested the use of both subjective and objective measures of performance in studies. In construction, it could be argued that soft indicators, which refer to the satisfaction with the interpersonal relations between project participants, emphasize the importance of collaboration between project participants in achieving project goals. Project participants' capability to cooperate with each other in the project has been found to have an impact on project success (Woodward, 1997; Karim and Adeli, 1999; Eden et al., 2000; Kärnä, 2009). The development of the collaboration between project participants has been emphasized strongly in the construction industry, since adversarial relationships have been identified as one of the main weaknesses in the industry (e.g. Latham, 2004; Humpreys et al., 2000; Naoum, 2000).

In turn, project complexity, can be interpreted and operationalized in terms of differentiation and interdependencies, which can be managed through project management actions such as coordination, communication and control (Baccarini, 1996). However, current project management frameworks and tools do not comprehensively correspond to the characteristics of project networks (El-Sheikh and Pryke, 2010) or the multi-faceted substance of project success (Jugdev and Moller, 2006). As a result, the performance of the construction industry as a whole tends to be scarce (Costa et al., 2006). Thus, a holistic view of performance measurements in the realm of multifaceted construction projects has been highlighted recently (Dainty et al., 2003; Chan and Chan, 2004; Leung et al., 2004; NzekweExcel, 2012; Lehtiranta et al., 2012).

Benchmarking is an important factor in performance measurement, which has been defined as "a continuous, systematic process for evaluating the products, services, and work processes of organizations that are recognized as representing best practices for the purpose of organizational 
Kärnä, S. and Junnonen, J-M (2016) Benchmarking construction industry, company and project performance by participants'evaluation.

improvement” (Spendolini, 1992). According to Yasin (2002), benchmarking is a multifaceted technique that can be utilized to identify operational and strategic gaps, and to search for best practices that would eliminate such gaps. Benchmarking helps companies to improve their performance by making changes to their policies and practices and by following the path of industry leaders who have demonstrated excellent performance (El-Mashaleh et al., 2007).

Yasin (2002) distinguishes two dimensions in benchmarking. Benchmarking has an internal dimension whereby an organization critically examines itself in search of best practices. The external dimension refers to organizations that search the industry in an attempt to identify external and competitive benchmarks. Additionally, benchmarking should lead to better customer service and satisfaction. Benchmarking as a process operates on two levels: as a method for measurement and a focus of activity. As a method of measurement, benchmarking assesses relative performance to establish metrics that reveal good performance. With regard to benchmarking being a focus for business activity, it looks at measuring the impact of initiatives that seek to attain, sustain and exceed both the performance and representational capability of these metrics.

\section{CLIENT AND PROJECT PARTICIPANTS' APPROACH}

Client satisfaction is a key success area and, for example, Barrett (2000) states that client satisfaction is the ultimate measure of construction quality. Client satisfaction could be determined by the extent to which a physical facility (product) and a construction process (service) meet and/or exceed a customer's expectations (Kärnä, 2009). It is also one of the essential attributes of total quality management (TQM), which construction firms are adopting in their quality improvement efforts (Lahndt, 1999; Burati et al., 1992). However, it has been noted that the construction industry has lagged behind other industries in implementing TQM, because of its inability to accurately determine client requirements and successfully transform these requirements into a completed facility (Ahmed and Kangari, 1995). Benchmarking is one central element of TQM, which promotes the principle of continuous learning with the help of an internal and external benchmark (Fisher et al., 1995). In construction it is suggested that benchmarking should cover the entire supply chain (Yasin, 2002).

The project stakeholder approach for measuring project success has been highlighted recently in construction. In general, stakeholders can be defined as groups or individuals who have a stake in or an expectation of a project's performance (Newcombe, 2003). A stakeholder may also exert influence over the project and its deliverables (PMI, 2004). In the construction context, project participants could be depicted as a project's internal stakeholders, including the project management organization, design team, construction contractor and other suppliers. Love and Holt (2000) state that the construction business performance measurement (BPM) has often been project-specific, profitorientated, and neglected broader "stakeholder" issues. They suggest implementing a stakeholder 
Kärnä, S. and Junnonen, J-M (2016) Benchmarking construction industry, company and project performance by participants'evaluation.

perspective measurement (SPM), utilizing multi-dimensional performance measures. Also Sommerville et al., (2000) underline that superior measures are those that incorporate internal and external customer survey findings which include the mapping of practical efforts centered on the perceptions of the client and other stakeholders in a construction project.

A previous analysis of industry-wide benchmarking results showed that the satisfaction of a participant with the performance of other participants reflects the success of a project (Lehtiranta et al., 2012). Project evaluation and feedback from project participants and clients have been identified as an important subset of changing project participants' behavior and providing effective reinforcement through informative and motivational properties (e.g. Trethewy, 2005). Also, project feedback can be seen as a vehicle for learning on the organizational level. For example, Argyris (1977) applies feedback and benchmarking to double loop organizational learning. The learning of an organization can be seen as constant circulation of functions, which include sensing the operational capability of the company and comparison with the operational capabilities of competitors.

However, project participants might have different perceptions towards the concept of project success, which can lead to difficulties in explicitly showing whether a project is successful or not (Lam et al., 2007). The satisfaction levels of construction clients and project participants can be enhanced by focusing on the values of their satisfaction attributes and improving the integration of the project team (Nzekwe-Excel et al., 2010). Similarly, Koutsikouri et al., (2008) remark that even though delivering a project on schedule and on budget are still dominant within the inter-disciplinary project organization, team members themselves are also interested in whether a project is worthwhile doing, satisfying and a good learning experience. Hence, measuring the project participants' satisfaction can be used in perceiving needs for development, mutual learning and to improve collaboration between the project participants (Kärnä et al., 2013).

\section{MUTUAL PROJECT EVALUATION}

The challenge to the construction industry is to develop and adapt an effective method for gathering and utilizing project participants' mutual performance evaluation to make project organizations and companies aware of operational problems and conflicts. On the other hand, the method should also support development and learning from past experiences. Multi-organizational project evaluation and benchmarking in the construction industry, which is recommended in the study, is an essential tool for several reasons. Construction project success depends on the ability of multiple organizations to work together (Lehtiranta et al., 2012) and to manage risks and learning (Cherns and Bryant, 1984). Typically, people with different roles and backgrounds who have not collaborated before are involved in the project organization. The objective of the mutual evaluation is to enhance the prerequisites of 
Kärnä, S. and Junnonen, J-M (2016) Benchmarking construction industry, company and project performance by participants'evaluation.

collaboration in the project and the participants' abilities to create value for one another and the project. Therefore, project evaluation should cover the most important parties in the supply chain.

According to Liu (1999), performance evaluation is a human behavioural phenomenon involving a cognitive perceptual process. Project performance has two attributes, at least: (1) the individual's expected performance (manifested as assigned goals); and (2) the individual's perceived actual performance. However, collecting and gathering evaluation data in the construction project alone is not enough. Essential is the ability to connect performance evaluation data with the learning of the organization (Choo, 2000). For example, Barnes (2003) notes that many customer feedback systems are doomed to fail before they begin. He argues that customer feedback systems can be successful only when that vital information is linked, aligned and deployed within the organization. The goal should always be concrete improvement of operations, quality and customer satisfaction, not mere measuring (Goodman, 2001). In construction, a lot of vital information remains unexploited because teams typically decompose after the project. The ability to take advantage of others' experiences to build up one's own body of knowledge is one of the most important sources of human and social development (Liang, 2004). Additionally, when people on building sites receive feedback on the construction process, the creativity of the employees is stimulated and incremental innovations and learning are enhanced (Bertelsen, 2004).

From the benchmarking perspective, project participants' mutual project evaluation has two main strengths. Initially, it can focus on an organization's core areas of business to help achieve the greatest added value for any improvement strategy. Second, after determining how a particular production process compares to others, it can focus on investigating how those with superior performance achieve their performance rates (Kärnä, 2009). Project evaluation is also a management tool, rooted in the business environment, that can be used to identify changes needed in production processes to improve performance. In brief, it involves analyzing an existing situation, identifying and measuring factors critical to the success of a production process, comparing them with the success factors of other companies, analyzing the results and implementing an action plan to improve performance.

In the logic and aspects of the project participants' mutual performance evaluation some similar features can be found as in 360 degree feedback, which has gained a lot of interest as a performance management tool. The term 360 degree feedback is commonly used for multiple sources feedback. According to Lepsinger and Lucia (1997), the 360 degree feedback process involves collecting perceptions about a person's behavior and the impact of that behavior from a number of rating sources. However, TQM was one of the main driving forces in the development of the feedback method. McCarthy and Garavan (2001) stated that 360 degree feedback acts as a very useful and 
Kärnä, S. and Junnonen, J-M (2016) Benchmarking construction industry, company and project performance by participants'evaluation.

powerful source of information because, with this method, customers and suppliers can provide feedback on various quality dimensions within the organization.

To our knowledge, there are no comparable, nationally agreed BM systems covering the entire construction industry worldwide. Although, for instance in Hong Kong a web-based construction project performance monitoring system has been developed (Cheung et al., 2004). Also Lee et al. (2005) presented a benchmarking system developed by the Construction Industry Institute (CII). The benchmarking system concentrates on collecting data about cost, schedule, safety, practice use and productivity. However, it collects information only of the hard measures, and not the performance of the project participants’ activities during the project.

As stated earlier, every project is unique and project participants evaluate projects from their individual perspectives. There is evidence that the mutual performance of project participants can be evaluated as an indicator of the ability of participants to provide value for one another. If information on performance is shared with other partners, then it could possibly improve the overall efficiency of the project. Therefore it is necessary to construct a standard method for project evaluations from project participants and clients. If project participants can predict the probability of success better, they can take steps to avoid unsuccessful projects and identify problems of current projects and take corrective action.

\section{MULTI-COMPANY BENCHMARKING IN FINLAND}

\section{Methodology and main features of the BM system}

The basic version of the project evaluation BM tool for the Finnish construction industry was developed between 2005 and 2007 as part of a joint research project between the Helsinki University of Technology, Construction Quality Association (RALA), and several industry and association partners. The goal of the research project was to develop a method of measuring and benchmarking project performance that will result in a repository of data for use by the industry and academia, and that will support a process of continuous improvement in the industry. RALA operates the system as a joint association that represents clients, contractors, and consultants. Its aim is to improve the prerequisites of construction quality by using certificates of competence, certificates of quality systems, and a project feedback system for clients and construction companies.

During the BM tool's development phase, a number of face-to-face meetings and workshops were held among the industry and association partners and the researchers. Also workshops with industry stakeholders were arranged. During the development phase, the following requirements and system properties were determined to be essential:

- The system should cover the entire industry and use a versatile Web interface 
Kärnä, S. and Junnonen, J-M (2016) Benchmarking construction industry, company and project performance by participants'evaluation.

- The central participants of a project should be involved in the system

- It should be possible to give and receive feedback (project evaluation) throughout the various stages of a project and to utilize the feedback during the project

- It should enable multipurpose benchmark comparisons

- It should be able to be adapted to different projects and forms of implementation

The questions were also developed and tested in the expert workshops. A total of five workshops were organized in 2005 and 2006. Each workshop had 10-15 participants from the strategic and tactical management of associations and companies as well as people responsible for development and quality matters in construction. The questionnaires were then piloted in real construction projects and finally in the production environment. The basis for the contents of the questions was formed by the various tasks in construction and the requirements they set for a construction project. The project evaluation questions concentrate on the matters that each project participant considers important, and, on the other hand, those that each participant can assess. The tasks and requirements of various participants in construction were grouped into fields that are similar to each other although the contents of the questions were determined by the role and task of the participant.

The basis of the system is standard evaluation, wherein the main participants evaluate each other's performances. The system identifies five role alternatives for the participants: client, project manager/consultant, architect/designer, main contractor, and sub-contractor. A standard feedback system may be considered more objective than a contractor's own project survey because social interaction components are not accounted for in the standard system (Kärnä, 2009).

In practice, the project manager or the representative of the main contractor establishes the project in the system and draws up a feedback plan. In the feedback plan, project information and participants are entered and the feedback evaluations are determined and started. The baseline of the feedback systematics is the mutual performance assessment, where all evaluations are bi-directional, and thus the feedback giver can evaluate one or multiple participants’ performance in the particular project. The questionnaire is answered electronically using an Internet form, which displays the project and participants’ performance being evaluated. After the feedback givers have evaluated the performance and completed the questionnaires, the evaluations are saved in the system and reported to the project participants. To clarify concepts used here, the term feedback flow depicts one particular performance evaluation between the project participants. The multi-directional network of project evaluations in the system is illustrated in Figure 1. 
Kärnä, S. and Junnonen, J-M (2016) Benchmarking construction industry, company and project performance by participants'evaluation.

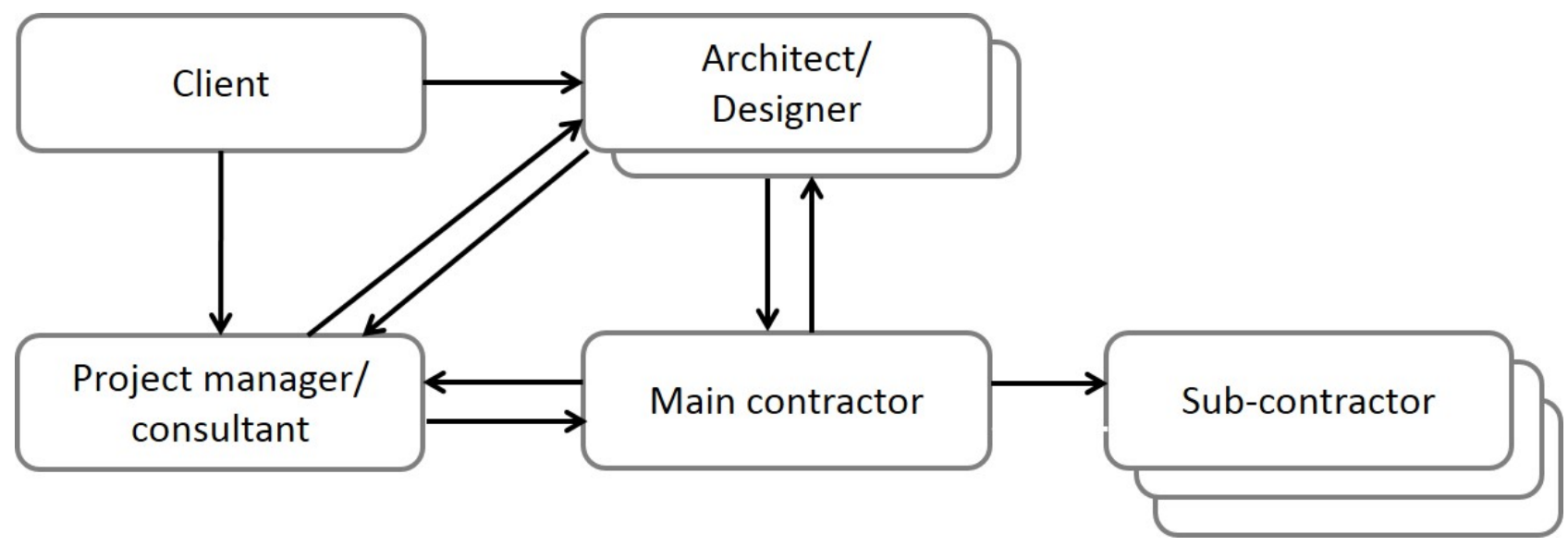

Figure 1. The multi-directional network of evaluation flows in the BM system.

The evaluation consists of 15 electronic questionnaires, which are specific to each evaluation (feedback) flow, such as the project consultant's evaluation of the main contractor's performance. The questionnaires can be adapted to fit the needs of a particular project. By comparing various background variables, a company can compare its performance with that of similar companies in the industry. Evaluation related to the operations of other project participants is provided after participants respond to statements regarding performance on a 5-point Likert scale, where 1 and 5 represent very low and very high satisfaction levels, respectively. The common evaluation categories are mainly (1) Project management, (2) Cooperation, (3) Staff, and (4) Goal accomplishment. Project management refers to general factors which have traditionally been measured through technical quality, costs, and schedule. Project management should be systematic and premeditated, and it should cover risk management and, for general contractors, effective management of subcontractors. Factors for measuring cooperation are, for instance, the functionality of cooperation, and factors related to information exchange and problem solving capabilities. The staff is strongly connected to skills and expertise and resource-related questions. Accomplishing goals naturally refers to the assessment of the attainment of various goals, which usually takes place after the project has been completed.

However, it is notable that mainly the categories are comparable with each other, but some categories are missing in some of the questionnaires. That is because these factors are not evaluated by the specific project participant. For example, the client does not evaluate the main contractor's staff, this is done by the project manager/consultant. In this case, the client might have e.g. an investor role and a distance to the project site so wide he/she cannot evaluate the contractor's staff properly and accurately. These kinds of exclusions have been made to the system for reasons related to the reliability and consistency of measurement. 
Kärnä, S. and Junnonen, J-M (2016) Benchmarking construction industry, company and project performance by participants'evaluation.

It is also important to make a distinction between process quality and technical quality. According to Grönroos (2000), the quality of a service has two dimensions. Technical quality is the outcome of the service production process. This is what the customer is left with when the production process is over. However, the customer is also influenced by the way in which the technical quality is transferred to him. This functional quality of the process is closely related to cooperation and encounters: how the customer experiences the production process. Arditi and Gunaydin (1997) have defined that it is the quality of the process that causes the product to be either acceptable or not. Process quality may refer to achieving quality in the way the project is organized and managed. They also emphasize that the construction industry should focus on process quality. In the construction supply chain, each participant is both a customer and a supplier, and the value created by them is a fundamental factor in the project's success (Love et al., 2000). As every participant's input is significant when producing good quality, this increases the relevance of developing tools that improve the cooperation between parties and includes both technical and process dimensions of quality.

\section{Different levels of benchmarking and reporting}

Companies need versatile information yielded by the benchmark system in order to be able to utilize the BM information in enhancing their own operations. The benchmark system offers clear, real-time benchmarking reports, which can be tailored to a company's products and processes, as shown in Figure 2. With the help of a simple Web interface, the system enables versatile benchmark comparisons between different projects and companies. By comparing various background variables, a company can compare its own performance with similar ones in the industry, which is illustrated in the upper left of Figure 2. The matrix in the upper right of Figure 2 depicts each evaluation flow between the project participants. The color of the column indicates the satisfaction levels, where dark green indicates high satisfaction levels and, in contrast, red color very low satisfaction levels. Accordingly, the management of the company can make observations about the performance at a glance. It is also possible to dissect evaluation flows one at a time (lower right of Figure 2), in which case it is possible to explore evaluation means by question groups. Also the trend line of the performance is presented by the classified question groups (lower left of Figure 2). Further, the system adapts to the needs of different companies since the structure and processes of business in the industry are very heterogeneous, so it can be utilized in, e.g., various forms of procurement methods and project types. The main content on the three levels of benchmark in the system are explained narrowly in Table 1. 
Kärnä, S. and Junnonen, J-M (2016) Benchmarking construction industry, company and project performance by participants'evaluation.

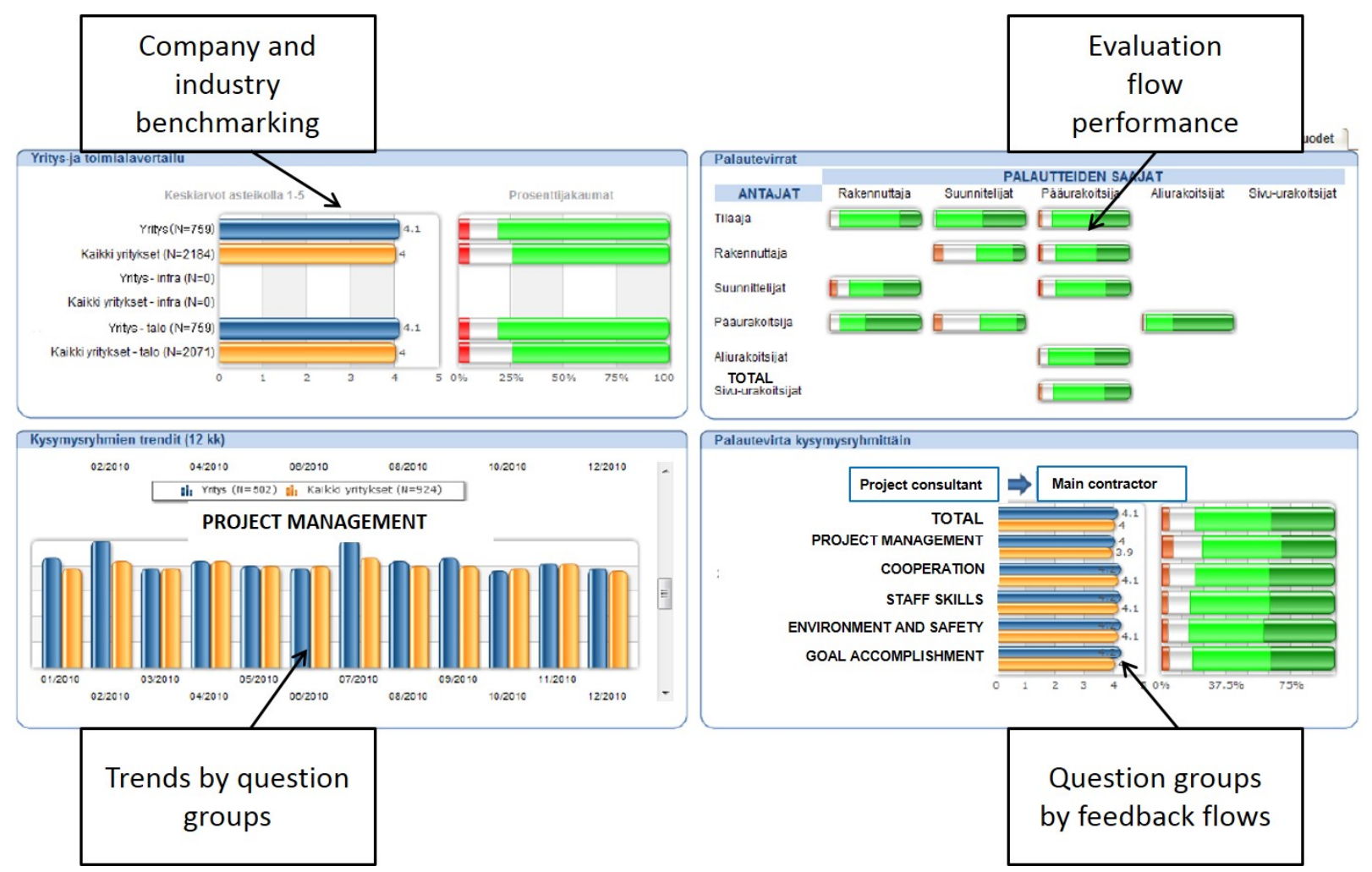

Figure 2. Illustrative dashboard of a company’s benchmarking results based on its project portfolio.

\begin{tabular}{|c|c|c|}
\hline $\begin{array}{l}\text { The level of } \\
\text { benchmark (BM) }\end{array}$ & Definition and objective & The content \\
\hline Project BM & $\begin{array}{l}\text { All participants get the static feedback } \\
\text { report which shows how their } \\
\text { performance has been assessed by the } \\
\text { other project participants. } \\
\text { The main objective of the project BM is to } \\
\text { increase professional competence and } \\
\text { learning on the individual level. Feedback } \\
\text { also enhances the teams' internal co- } \\
\text { operation. }\end{array}$ & $\begin{array}{l}\text { Performance in each question presented by } \\
\text { the average value and question specific } \\
\text { standard deviations. } \\
\text { Reference levels in the reports consist of: } \\
\text { (1) the performance in all feedback directed } \\
\text { to the same feedback flow in the project } \\
\text { (2) the performance in all feedback directed } \\
\text { to the same feedback flow in the whole } \\
\text { BM database. }\end{array}$ \\
\hline Internal BM & $\begin{array}{l}\text { Benchmarking reports can be tailored and } \\
\text { scaled to a company's products and } \\
\text { processes through the dashboard } \\
\text { interface. } \\
\text { The main objective of the internal BM is } \\
\text { to develop organizational competence and } \\
\text { monitor the needs for development. }\end{array}$ & $\begin{array}{l}\text { Internal BM comparisons can be made by } \\
\text { comparing the performance of the projects } \\
\text { with each other by classifying projects } \\
\text { according to the company's needs. } \\
\text { Additionally, it provides initial data for } \\
\text { customer relations management, quality } \\
\text { management and e.g. rewarding the staff. }\end{array}$ \\
\hline External BM & $\begin{array}{l}\text { The main objective of the external BM is } \\
\text { to position an organization's performance } \\
\text { in comparison to the market. The external } \\
\text { BM enhances and supports the company's } \\
\text { strategical decisions. }\end{array}$ & $\begin{array}{l}\text { To enhance and improve co-operation, } \\
\text { customer relationship management and } \\
\text { quality } \\
\text { Strategic performance management, e.g. } \\
\text { monitoring the company's strengths and } \\
\text { weaknesses. }\end{array}$ \\
\hline
\end{tabular}

Table 1 . The content of the different levels of benchmarking. 
Kärnä, S. and Junnonen, J-M (2016) Benchmarking construction industry, company and project performance by participants'evaluation.

\section{OBSERVATIONS FROM THE BENCHMARK DATA}

As discussed in the study, a multi-firm project BM supports the efforts of construction companies to establish industry benchmarks and to improve performance on various organizational levels. Performance measurement and benchmarking should be used as a way to generate value for companies and stakeholders to increase the levels of effectiveness and efficiency. However, they also support development efforts in the whole branch of industry. This extensive national database has been used for research activities for many purposes. Industrial performance has been investigated from the viewpoint of the performance of the different types of construction projects (Kärnä et al., 2013), and risk management (Lehtiranta, 2014). Also, Finnish BM data have been used to explore the role of multi-firm satisfaction in construction project success (Lehtiranta et al., 2012) and to examine the concept of customer satisfaction in construction (Kärnä, 2009).

The project evaluation BM system has accumulated over 5,500 performance evaluation results, representing over 1,100 projects by the year 2014. The authors got the access to BM-data as an initiative of the Construction Quality Association and the aim was to explore quantitatively the current situation of the performance of the Finnish construction industry.

The main evaluation results of the participants' performance are summarized in Figures 3 and 4. In the Figures, values are mean scores on how each participant's performance has been evaluated by others classified by the main categories on a scale of $1-5$. The values in the table form the industrywide benchmarking results, which enable individual companies to compare performances. Higher values indicate and showcase a competitive advantage for the specific factors.

When analyzing BM mean values exploratively, an extensive picture of the current state of the main participants' performance can be obtained. In general, the results show that the general levels of performance evaluations for project participants in the Finnish construction industry are high, as represented by a score just under or above 4. It can be perceived that main contractors' and project consultants’ performance has been evaluated very similarly in all areas (Figure. 3). It is also noteworthy that designers' performance has been evaluated poorly in all areas by main contractors and similarly sub-contractors’ performance related to project management tasks (Figure 4). 
Kärnä, S. and Junnonen, J-M (2016) Benchmarking construction industry, company and project performance by participants'evaluation.
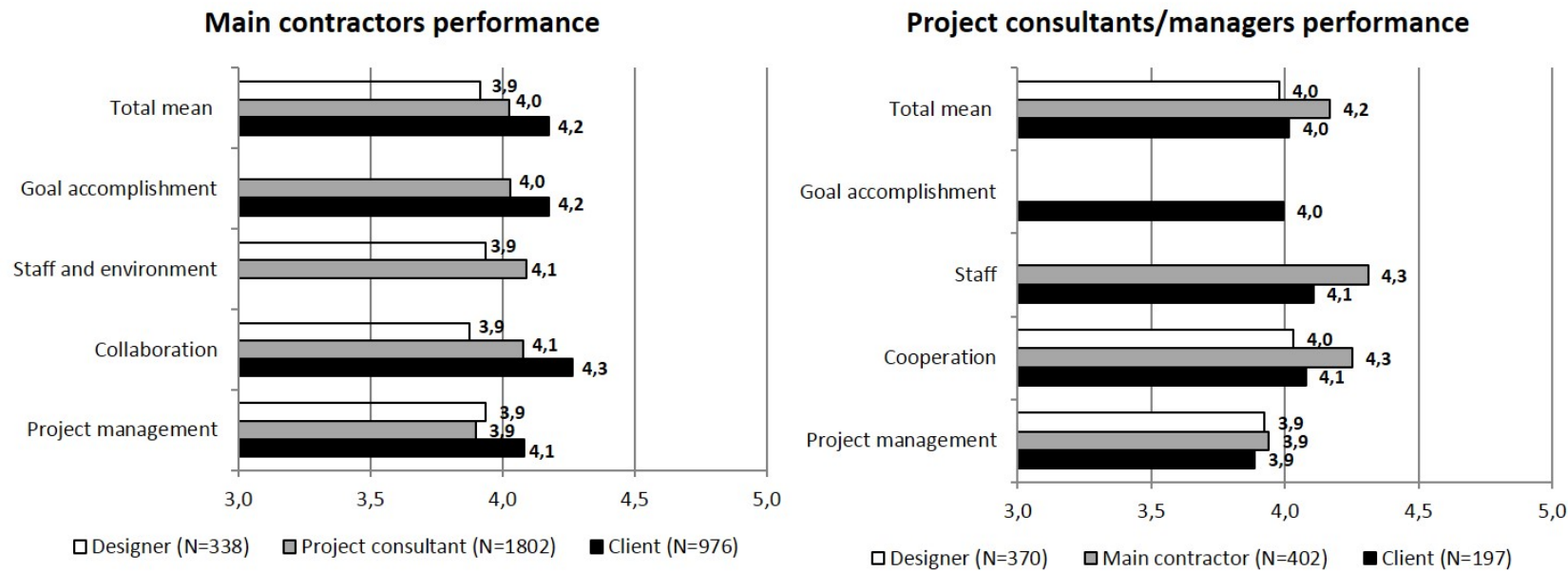

Figure 3. The national benchmark results for main contractors' and project consultants'/managers' performance in the Finnish construction industry - mean values of the satisfaction of the project participants' evaluation.
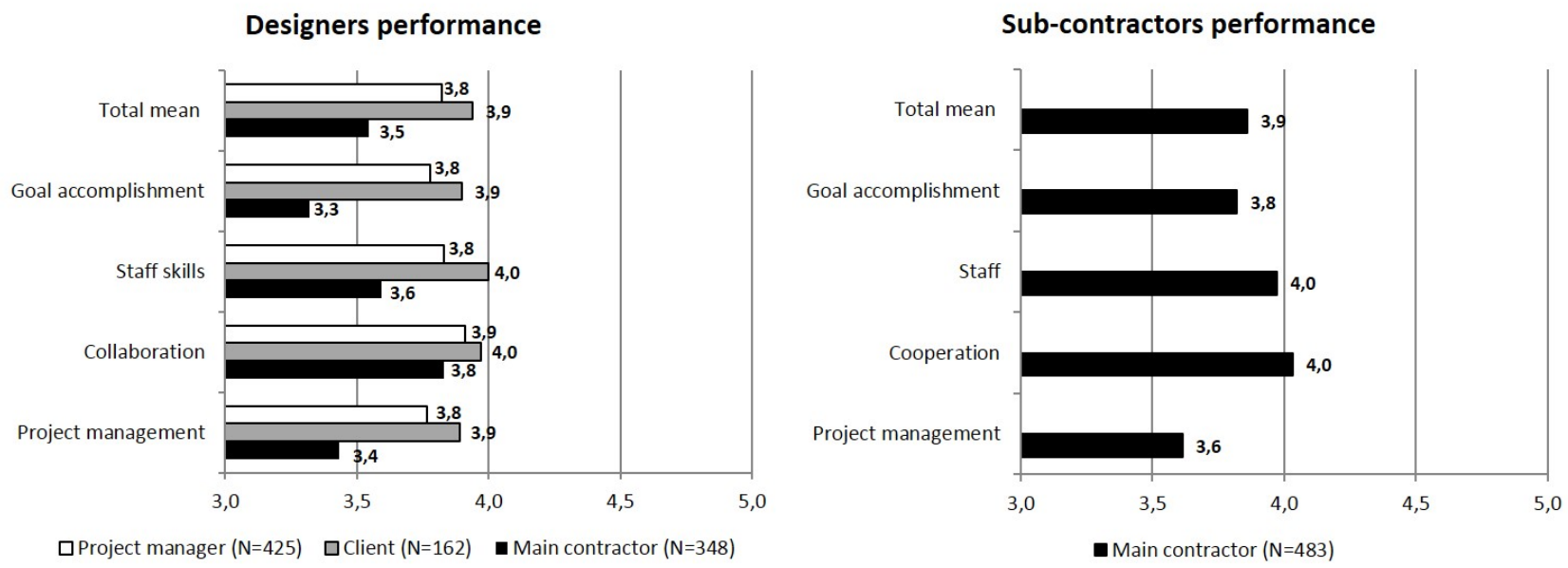

Figure 4. The national benchmark results for designers' and sub-contractors' performance in the Finnish construction industry - mean values of the satisfaction of the project participants' evaluation.

The project management performance of the participants can be identified as a factor yielding somewhat lower evaluations than the other factors for a company. Conversely, staff members and their ability to collaborate are generally evaluated highly. This is somewhat surprising, because there has been a perception that adversarial relationships affect project participant evaluation of the collaboration during a project. However, the result can be interpreted so that process quality can compensate for the weaknesses of technical quality, at least to some extent.

All in all, the results indicate that quality, as reflected in the BM data related to project management, cooperation, staff skills, environment and safety, and goal accomplishment, is on a rather high level in the Finnish construction industry. This might also be a result of the long-term development work, 
Kärnä, S. and Junnonen, J-M (2016) Benchmarking construction industry, company and project performance by participants'evaluation.

in which quality has been in focus in many national level research initiatives led by both the academia and the industry, e.g. The Confederation of Finnish Construction Industries RT (CFCI).

However, some areas for development can also be derived from the BM data. In general, development areas are related to project management, especially to factors related to risk management, project documentation, and sub-contractors' guidance. The latter seems to be the weakest link in construction. However, the problem is thus not just the poor performance of sub-contractors. It is also a question, on one hand, of project management and leadership, and, on the other hand, of control and quality assurance throughout the whole supply chain. These are all challenging tasks especially when projects are becoming more complex and technically advanced. Additionally, the lower level of the designer's performance than other participants' is consistent with other studies in the field (Koutsikouri et al., 2008; Toor and Ogunlana, 2009).

One of the key aspects and also a limitation of interpreting results of the BM system refers to the subjective nature of the assessment method. Benchmarking results in the system are based on a participant's self-assessment towards other project participants' performance. However, in the survey generated by the BM system in a project, respondents are instructed to assess the management of the tasks related to construction management, design, and construction - not the individual as such. Also, in the cover letter there is a note to the respondents that this is a development tool, where professionals are assessing each other. This encourages respondents to an honest and fruitful evaluation. In addition, it has been examined that the validity of subjective measures is comparable to more objective measures (Wall, 2004).

\section{CONCLUSIONS}

The article introduces a multi-company project benchmarking tool and presents national benchmark levels for the main participants in the Finnish construction industry based on seven years of multidirectional performance measurements. Benchmarking is a process of organizational adaptation where the focus is on learning how to improve organizational performance. Thus, it is a powerful concept with a change agent impacting on behavior modification and developing new ways to manage business. Recent project success literature suggests that project participants' satisfaction is one of the key factors affecting it. As part of the complex and dynamic construction industry, multi-directional project evaluation responds to the needs of performance measurements and corresponds to wider perceptions of project success, including satisfaction with the process.

In the project-based construction industry, multi-company evaluation can be used to identify participants' levels of performance and development needs. However, specific features of construction, such as changes in project organization, the uniqueness of each project and project 
Kärnä, S. and Junnonen, J-M (2016) Benchmarking construction industry, company and project performance by participants'evaluation.

parties' different objectives, set challenges for developing an effective evaluation and performance measurement system to the needs of the project-based industry. Thus, a well-functioning and efficient benchmark and project evaluation system takes into account the dependencies of the main participants' performance and the special features of the construction project. As a common system for the parties in the industry, the project evaluation BM system promotes quality improvement, customer orientation and collaboration between the participants.

A construction project should be considered as a process where all customers must be satisfied. These customers include internal customers (employees, units, departments within an organization) and external customers (owner, designer, contractor, etc.). To achieve sustained success, an organization needs to develop and improve their people, partnerships, and processes to deliver value-adding products to their external customers.

Project evaluation amongst the main participants can be used on several levels: to detect performance problems and identify improvements during a project for the purpose of risk management; to identify improvement needs after a project for the purpose of learning; to analyze project portfolios for the purpose of business improvement; to evaluate existing shortcomings versus industry leaders; and to accumulate results in an evaluation database for the purpose of industry analysis. As project performance results accumulate over time, the data can be used to establish discipline-specific industry-wide benchmarks. BM tools can be used also for improving the status of the quality management system within organizations. Benchmarking promotes the principle of continuous learning and TQM. Process quality aims at the smooth functioning of the organization's internal processes and reducing the variation of performance in internal processes.

In Finland, multi-company benchmarking promotes the performance of consultants, main contractors, architects/designers, and sub-contractors of a construction project, supports client orientation, and contributes to collaboration. Based on extensive BM data, the performance of construction is on a good level and, on average, the parties are satisfied with each other's performance. However, according to the results, the main development targets of the construction industry are related to the development of methods of risk management and managing design. Also, the selection procedures of sub-contractors should be developed in such a way that greater weight would be given to subcontractors' professional know-how and ability to produce quality. Currently, sub-contractors' selection is excessively based on price components and expertise is faded into the background.

Finally, companies that exceed the national benchmarks have a competitive advantage. However, only a limited and selected group of companies have adopted the benchmarking system so far. It is very likely that these companies represent the best of the industry anyway, which is reflected in the 
Kärnä, S. and Junnonen, J-M (2016) Benchmarking construction industry, company and project performance by participants'evaluation.

good results. It is obvious that more companies and public organizations need to adopt the system and also take full advantage of its features and possibilities, e.g. take use of all main participants' mutual evaluations on the project level.

Further research is recommended to establish similar performance information measurement systems in other countries to enable national and international comparisons. Also end-users' satisfaction, as an important stakeholder of the whole construction and real-estate cluster, should be connected to the $\mathrm{BM}$ system. This would complement the measurement of the soft indicators and strengthen the assumptions of the dynamics of quality in construction in the whole project life-cycle.

\section{Acknowledgements}

The authors acknowledge Finnish Construction Quality Association (RALA) for the collaboration and constructive contributions, which has made the study possible. 
Kärnä, S. and Junnonen, J-M (2016) Benchmarking construction industry, company and project performance by participants'evaluation.

\section{REFERENCES}

Ahmed, S.M. and Kangari, R. (1995), Analysis of client-satisfaction factors in construction industry. Journal of Management in Engineering. Vol. 11 No. 2, pp. 36-44.

Arditi, D. and Gunaydin, H.M. (1997), Total quality management in the construction process. International Journal of Management, Vol. 15 No. 4, pp. 235-343.

Argyris, C. (1977), Organizational learning and management information systems. Accounting Organizations and Society, Vol. 2 No. 2, pp. 113-23.

Baccarini, D. (1996), The concept of complexity-A review. International Journal of Project Management, Vol. 14 No. 4, pp. 201-204.

Ball, M. (1988), Rebuilding Construction: Economics Change in the British Construction Industry, Routledge, London.

Barnes, W.R. (2003), Designing customer satisfaction programs for actionability. Quality Congress. ASQ’s...Annual Quality Congress Proceedings; 57.

Barrett, P. (2000), Systems and relationships for construction quality. International Journal of Quality and Reliability Management, 17(4), 377-92.

Beatham, S., Anumba, C., Thorpe, T., and Hedges, I. (2004), KPIs: A critical appraisal of their use in construction. Benchmark, Vol. 11. No. 1, pp. 93-117.

Bertelsen, S. (2004), Lean Construction: Where are we how to proceed? Lean Construction Journal, Vol. 1, pp. 46-69.

Bititci, U.S., Carrie, A.S. and McDevitt, L. (1997), Integrated performance measurement systems: a development guide, International Journal of Operations \& Production Management, Vol. 17 No. 5, pp. 522-34.

Burati, J.L., Matthews, M.F. and Kalindi, S.N. (1992), Quality management organizations and techniques. Journal of Construction Engineering and Management. Vol. 118 No. 1, pp. 112-128.

CCI Centre for Construction Innovation, (2004), An introduction to Key Performance Indicators. Constructing excellence in the North West.

Chan, A.P.C. and Chan, A.P.L. (2004), Key performance indicators for measuring construction success. Benchmarking: An International Journal, Vol. 11 No. 2, pp. 203-221.

Cherns, A.B. and Bryant, D.T. (1984), Studying the client's role in construction management. Construction Management \& Economics, 2(2), pp.177-184.

Cheung, S.O., Tam, C.M., Ndekugri, I. and Harris, F.C. (2000), Factors affecting clients project dispute resolution satisfaction in Hong Kong. Construction Management and Economics, Vol. 18 No. 3, pp. 281-294.

Cheung, S.O., Suen, H.C.H and Cheung, K.K.W. (2004), PMMS: a Web-based construction Project Performance Monitoring System. Automation in Construction, 13. pp. 361-376.

Choo, C.W. (2000), Information Management for the Intelligent Organization. The Art of Scanning the Environment. 2nd ed. Medford: Information Today Inc.

Costa, D.B., Formosa, C.T., Kagioglou, M., Alarcón, L.F. and Caldasm, C.H. (2006), Benchmarking Initiatives in the Construction Industry: Lessons Learned and Improvement Opportunities. Journal of Management in Engineering, October, 22, pp. 158-167. 
Kärnä, S. and Junnonen, J-M (2016) Benchmarking construction industry, company and project performance by participants'evaluation.

Dainty, A., Cheng, M. and Moore, D. (2003), Redefining performance measures for construction project managers: an empirical evaluation. Construction Management and Economics, Vol. 21, pp. 209-218.

Eden, C., Williams, T., Ackermann, F. and Howick, S. (2000) The role of feedback dynamics in disruption and delay (D\&D) in major projects. Journal of the Operational Research Society, 51(3), 291-300.

El-Mashaleh, M.S., Minchin, R.E. and O’Brien, W.J. (2007), Management of construction firm using benchmarking. Journal of Management Engineering, Vol. 23. No. 1, pp. 10-17.

El-Sheikh, A. and Pryke, S.D. (2010), Network gaps and project success. Construction Management and Economics, 28(12), pp. 1205-17.

Fisher, D., Miertschin, S. and Pollock, D.R. (1995). Benchmarking in Construction Industry. Journal of Management in Engineering, Vol. 11 No. 1, pp. 50-57.

Garvin, D. (1993), Building a Learning Organization. Harvard Business Review (July - August), pp. 78-91.

Goodman, J. (2001), Using Complaints for Quality Assurance Decisions. International Journal of Customer Relationship Management. Vol. 4 (June/July), pp. 59-72.

Grönroos, C. (2000), Service Management and Marketing. A Customer Relationship Management Approach. 2nd edition, John Wiley \& Sons, pp. 63-65.

Hellard, R. B. (1993). Total quality in construction projects, Telford, London.

Humpreys, P., Matthews, J. and Kumaraswamy, M. (2003) Pre-construction project partnering: from adversarial to collaborative relationships, Supply Chain Management: An International Journal, Vol. 8 Iss: 2, pp. 166 - 178

Jugdev, K. and Moller, R. (2006), A retrospective look at our evolving understanding of project success. IEEE Engineering Management Review, 34(3), pp. 110-127.

Kanji, G.K. and Wong, A. (1998) Quality culture in the construction industry. Total Quality Management, 9 (4/5), 133-140.

Karim, A. and Adeli, H. (1999), CONSCOM: an OO construction scheduling and change management system. Journal of Construction Engineering \& Management, 1(5), 368-78.

Koutsikouri, D., Austin, S. and Dainty, A. (2008), Critical success factors in collaborative multidisciplinary design projects. Journal of Engineering, Design and Technology, Vol. 6 Iss: 3 pp. 198226.

Kumaraswamy, M.M. and Thorpe, A. (1996), Systematizing Construction Project Evaluations. American Society of Civil Engineers Journal of Management in Engineering, 12, 1, pp. 34-39.

Kärnä, S. (2009), Concepts and Attributes of Customer Satisfaction in the Construction. Doctoral dissertation, TKK-R-DISS-2. Helsinki University of Technology.

Kärnä, S., Junnonen, J-M., Manninen, A-P., Julin, P. (2013), Exploring project participants' satisfaction in the infrastructure projects. Engineering Project Organisation Journal, Vol. 3 Iss: 4, pp.186-197.

Lam, E.W.M., Chan, A.P.C. and Chan, D.W.M. (2007), Benchmarking the performance of designbuild projects, development of project success index. Benchmarking: An International Journal, Vol. 14 No. 5, pp. 624-638.

Lahndt, P.E.L. (1999), TQM tools for the construction industry. Engineering Management Journal, Vol. 11 No 2, pp. 23-27. 
Kärnä, S. and Junnonen, J-M (2016) Benchmarking construction industry, company and project performance by participants'evaluation.

Latham, M. (1994), Constructing the team. London: HMSO, 1994.

Lee S-H., Thomas S.R. \& Tucker R.L., Web-based benchmarking system for the construction industry. Journal of Construction Engineering and Management, Vol. 131, No. 7, July 1, 2005. pp790-798

Lehtiranta, L., Kärnä, S. Junnonen, J.-M. and Julin, P. (2012), The role of multi-firm satisfaction in construction project success. Construction Management and Economics, (June 2012) 30, pp. 463475.

Lehtiranta, L. (2014), Collaborative risk management in complex construction projects. Aalto University publication series DOCTORAL DISSERTATIONS, 48/2014.

Lema, N. M., and Price, A. D. F. (1995). Benchmarking: Performance improvement toward competitive advantage. Journal of Management in Engineering, 11(1), pp. 28-37.

Lepsinger, R. and Lucia, A. (1997), The Art and Science of 360[degrees] Feedback, Jossey-BassPfeiffer, San Francisco, CA.

Leung, M.-Y., Ng, S.T. and Cheung, S.-O. (2004), Measuring construction project participant satisfaction, Construction Management and Economics, 22(3), pp. 319-331.

Liang, Y. (2004), Benchmarking Theory Applied to State Parks: An Exploratory Study, Oklahoma State University, Stillwater, OK.

Liu, A.M.M. and Walker, A. (1998), Evaluation of project outcomes. Construction Management and Economics, Vol. 16, pp. 209-216.

Liu, A.M.M. (1999), A research model of project complexity and goal commitment effects on project outcome, Engineering, Construction and Architectural Management, Vol. 6 Iss 2 pp. 105 - 111.

Love, P.E.D, Smith, J, Treloar, G.J. and Li, H. (2000), Some empirical observations of service quality in construction. Engineering Construction and Architectural Management. Vol.7 No.2, pp.191-201.

Love, P.E.D. and Holt, G.D. (2000), Construction business performance measurement: the SPM alternative, Business Process Management Journal, Vol. 6 Iss: 5 pp. 408-416.

McCarthy, A.M. and Garavan, T. (2001), 360[degrees] feedback process: performance, improvement and employee career development Journal of European Industrial Training, 25, 1, pp. 5-32.

Mohamed, S. (1996), Benchmarking and improving construction productivity. Benchmarking: An International Journal, Vol. 3 Iss: 3 pp. 50-58.

Naoum, A. (2003), An overview into the concept of partnering. International Journal of Project Management, 21, pp. 71-76.

Nasir, H., Haas, C.T., Rankin J.H., Fayek, A.R., Forgues, D. and Ruwanpura, J. (2012), Development and implementation of a benchmarking and metrics program for construction performance and productivity improvement. Canadian Journal of Civil Engineering, Vol. 39, pp. 957-967.

Newcombe, R. (2003), From client to project stakeholders: A stakeholder mapping approach, Construction Management and Economics, Vol. 21 No. 8, pp 841-848.

Nzekwe-Excel, C., Nwagboso, C., Georgakis, P. and Proverbs, D. (2010), Integrated framework for satisfaction assessment in construction sector. Journal of Engineering, Design and Technology. Vol. 8 No. 2, pp. 168-188.

Nzekwe-Excel, C. (2012), Satisfaction assessment in construction projects: a conceptual framework. Built Environment Project and Asset Management, Vol. 2 Iss: 1, pp. 86-102.

Pheng, L.S. and Ke-Wei, P. (1996), A framework for implementing TQM in construction, The TQM Magazine, Vol. 8 Iss: 5, pp. 39-46. 
Kärnä, S. and Junnonen, J-M (2016) Benchmarking construction industry, company and project performance by participants'evaluation.

Project Management Institute, PMI (2004), A guide to the project management body of knowledge. ANSI/PMI 99-001-2004, Newton Square, PA.

Sommerville, J., Hamish W. and Robertson, H.W . (2000), A scorecard approach to benchmarking for total quality construction, International Journal of Quality \& Reliability Management, Vol. 17 Iss: 4 pp. 453-466.

Spendolini, M.J. (1992), The benchmarking book. AMACOM, American Management Association, New York.

Toor, S. and Ogunlana, S. (2009), Construction professionals' perception of critical success factors for large-scale construction projects, Construction Innovation, Vol. 9 Iss: 2, pp. 149-167.

Trethewy, R.W. (2005), The effect of feedback on risk taking in the Australian construction industry. Journal of Engineering, Design and Technology, Vol. 3 Iss: 2 pp. 109-115.

Wall, T.D., Mitchie, J., Patterson, M., S.J., Sheehan, M., Clegg, C.W. and West, M. (2004), On the validity of subjective measures of company performance. Personnel Psychology, 57, pp. 95-118.

Wang, X.J. and Huang, J. (2006), The relationships between key stakeholders' project performance and project success: perceptions of Chinese construction supervising engineers. International Journal of Project Management, 24(3), 253-60.

Woodward, J.F. (1997), Construction project management: getting it right first time, Thomas Telford, London.

Vidal, L.-A. (2011), Understanding project complexity: implications on project management. International Journal of Project Management 29, pp. 718-727.

Yasin, M. (2002), The theory and practice of benchmarking: then and now, Benchmarking: An International Journal, Vol. 9 Iss: 3 pp. 217-243. 